\section{EMBRYRIDDLE}

Aeronautical University

SCHOLARLY COMMONS
Journal of Aviation/Aerospace

Education \& Research

Volume 2

Number 3 JAAER Spring 1992

Article 1

Spring 1992

\title{
An Assessment of the Impacts of Congestion Delay at Major \\ Hubs to Airlines and Passengers
}

Atef Ghobrial Ph.D.

Ken Fleming Ph.D.

Follow this and additional works at: https://commons.erau.edu/jaaer

\section{Scholarly Commons Citation}

Ghobrial, A., \& Fleming, K. (1992). An Assessment of the Impacts of Congestion Delay at Major Hubs to Airlines and Passengers. Journal of Aviation/Aerospace Education \& Research, 2(3). https://doi.org/ 10.15394/jaaer.1992.1071

This Article is brought to you for free and open access by the Journals at Scholarly Commons. It has been accepted for inclusion in Journal of Aviation/Aerospace Education \& Research by an authorized administrator of Scholarly Commons. For more information, please contact commons@erau.edu. 


\section{Ghobrial and Fleming: An Assessment of the Impacts of Congestion Delay at Major Hubs to \\ AN ASSESSMENT OF THE IMPACTS OF CONGESTION DELAY AT MANOR HUBS TO AIRLINES AND PASSENGERS}

Atef Ghobrial, Ph.D. and Ken Fleming, Ph.D.

\section{ABSTRACT}

Of the 544 hubs in the U.S., only 28 accounted for 73.03\% of passenger enplanements in 1989. (Transportation Research Board, 1988). Despite some of the economic benefits of hubbing at those few hubs, congestion delay seems to affect airlines, passengers, airports, Air Traffic Control (ATC) facilities and the environment. This paper attempts to quantify the magnitude of congestion costs to airlines and passengers. The analysis should prove useful in assessing aviation policy, evaluating projects, and allocating resources among different airports in the U.S.

\section{INTRODUCTION}

The phenomenon of hubbing has been on the rise since airline deregulation in 1978. The nowfamiliar pattern of multiple links emanating from a handful of hub airports has replaced the seeming hodgepodge that characterized many network systems under regulation. Hubbing occurs when airlines concentrate flights at a few airports that they use as collection-distribution centers for their passengers. Unlike the situation in the early days, when airlines had to make technical refueling stops, today's hubbing is motivated by the economic advantages of increased flight frequencies and by the economic advantage of operating larger aircraft. By consolidating passengers through a few selected airport hubs, an airline takes advantage of the resulting higher traffic volumes by operating relatively large and efficient aircraft; thus enjoying the economies of aircraft size (Kanafani \& Ghobrial 1982). The airline can also raise the frequency of service it offers passengers to offset the increased travel time occasioned by the need to transfer. Moreover, by concentrating aircraft operations at a few hubs, an airline can dominate those hubs and take advantage of the phenomenon of the S-curve disproportionality between its enplanement share and frequency share at the hub airport; an airline with higher frequency share will capture even a higher enplanement share than its frequency share, and conversely, (Miller, 1979, Ghobrial, 1991).

By dominating a hub an airline can also charge higher airfares to passengers originating from the hub region; thus, an airline can achieve higher profits. Using time-series data for a number of airlines (Ghobrial, 1991) found a positive and statistically significant relationship between an airline profitability index (measured by the percentage of airline profits divided by its revenue) and its frequency share at the main hub.

Despite the inconvenience of transfer at the hub airport and the possibility of missing a connecting flight or losing baggage at the destination airport, hubbing has many benefits to passengers. For instance, passengers flying in thin traffic markets may not enjoy low airfares or flying in large jets if the airlines were to fly them nonstop between the end cities. Small airplanes cost more per-seat mile to operate and may require multiple technical stops for refueling. In fact, through multiple hub systems, passengers from small cities (e.g., Mobile, Alabama; Athens, Georgia; Greenville, South Carolina; etc.) can fly to any small and large cities in the world with relatively low airfares. Through connecting at a hub, passengers can also enjoy the convenience of frequent flights to and from that hub. This usually results in lower schedule delay which is defined as the waiting time between a passenger's most desirable departure time and the actual scheduled flight (Douglas \& Miller, 1974). Flying large-size jets also increases the chances of finding a seat on the passenger's desired flight.

NEGATIVE IMPACTS OF CONCENTRATION

While hubbing seems to benefit airlines, and offers some advantages to passengers, excessive concentration at the hub may result in some negative economic impact, including congestion delay. As aircraft volume approaches the capacity of the hub airport congestion delay increases rapidly, which may outweigh some of the bene- 
fits of hubbing for both airlines and passengers. This additional delay increases the total travel time of passengers and adds to the operating costs of airlines (i.e., wages for the crew and flight attendants, fuel and maintenance expenses for the airplane and engines). Congestion delay also causes additional work loads and increased stress levels for air traffic controllers. It may require upgrading the ATC facilities and adding more personnel at the ATC centers and airport towers. Excessive aircraft concentration at the hub can have adverse environmental impacts such as noise and pollution. These potential negative economic impacts of aircraft concentration should be taken into account when conducting a benefit-cost analysis for building or expanding major hubs.

The purpose of this paper is to devise an approach to quantify some of the negative impacts of congestion at major hubs. The analysis should prove useful for assessing aviation policy, evaluating projects, and allocating resources among different airports in the U.S. Ideally, one would be interested in assessing the impacts of delay on the different components of the aviation system: airlines, passengers, airports, ATC, and the environment. This task requires developing sophisticated models and obtaining large volumes of data. The analysis presented here falls considerably short of this ideal. This paper attempts to quantify the magnitude of congestion costs to both airlines and passengers. To illustrate our analysis, we use William B. Hartsfield International Airport (AtlantaAirport/Hartsfield Airport) as a case study in this paper. Atlanta Airport is the second busiest airport in the United States, and more than $65 \%$ of its enplanements are connecting passengers.

\section{CONGESTION COSTS TO AIRLINES}

To estimate congestion costs to airlines at a particular hub, one would need to obtain detailed data on flight arrivals and departures by aircraft type, the delay pattern by the Time-of-Day, and the airline unit cost of crew, fuel, and maintenance. Because of the complexities of how airline costs are affected by delay, some reasonable assumptions should be made when assessing these costs. For instance, while estimating the crew cost for originating or terminating flights is relatively straightforward, it is a bit cumbersome in the case of connecting flights. For example, a delayed flight arriving at Hartsfield may still be able to depart on time for its next flight leg; thus, the extra airborne crew cost is, to some extent, compensated for by less ground time. Likewise, a departing flight can be held at the gate with engines shut off until it is allowed to taxi out; thus little costs are incurred. To simplify the analysis, we assume that for arriving aircraft, airlines incur additional costs for crew and flight attendants, fuel for circulating around the airport, and maintenance. For simplicity, assuming that aircraft are held at the gates, we ignore the delayrelated costs for departing aircraft. This is a more consenvative approach since it is common to see aircraft queuing on the taxiways leading to runway thresholds for take-off. Based upon the above assumptions, the congestion delay cost for an airline is formulated as:

Equation No. 1

$$
A C=\left(\sum_{1} 8 \sum_{m} F Q_{l}^{m}\left(C_{m}+F_{m}+M_{m}\right)\right)
$$

Where: $\begin{aligned} & A C= \begin{array}{l}\text { Airline cost due to } \\ \text { congestion delay }\end{array} \\ & \delta_{1}= \begin{array}{l}\text { Average delay (in hours) } \\ \text { for arriving aircraft in } \\ \text { period } i\end{array} \\ & F_{1}^{m}= \begin{array}{l}\text { Number of aircraft of } \\ \text { type } m \text { arriving during }\end{array} \\ & \text { period } i\end{aligned}$ we consider two time periods: peak and off-peak periods. Flights during peak periods are estimated as the sum of morning peak flights (i.e., between 6:01 and 9:00 am) and evening peak (i.e., between 4:01 and 7:00 pm). Off-peak flights are calculated as the sum of those operated before 6:01 am, between 9:01 am and 4:00 pm, and after 7:00 pm. Congestion Costs To Airlines at Atlanta Alrport

To demonstrate our approach of estimating congestion costs to airlines, we apply Equation 1 to 
the case of airline operations at Hartsfield Airport in 1986. The delay for aircraft arriving at Atlanta Hartsfield during a given period can be estimated using queuing or simulation techniques (Horonjeff \& McKelvey, 1983. This approach, however, requires collecting a large and expensive volume of field data, a process beyond the scope of this study. Here we devise a simple technique based on regression procedure. We regress the travel time against distance for 314 non-stop flights operated by Delta Airlines in 1986. These markets consist of two groups: (a) flights originating at uncongested hubs and terminating at Atlanta Hartsfield and (b) flights operating between uncongested small and medium hubs. Of these, there were 163 flights operating during morning and evening peak periods. Data on travel time and distance for each market were obtained from the system timetable for Delta Airlines in June 1986. Note that airlines do attempt to add a reasonable estimate of delay to the travel time in their published schedules; thus, the estimated delay at Hartsfield Airport, using the published timetable, reflects schedule delay due to congestion rather than to mechanical problems or weather. To estimate the delay at Hartsfield Airport, we used a dummy variable (ATL) for flights termi- nating at Atlanta. The relationship between travel time and distance is given as:

Equation No. 2

$T_{1 j}=a_{1}+b_{1} D_{1}+d_{1} A T L+e_{1}$

Where $T_{\| j}$ is the flight time in hours in market $j$ for aircraft arriving during period $i, D_{1}$ is the distance in statute miles between the end cities in market $j$ and ATL is a dummy variable that takes on the value one for flights arriving at Atlanta Hartsfield Airport, and zero othenwise. $a_{1}, b_{1}$ and $d_{1}$ are the estimated parameters for period $i$ and $e$ is the error term. The estimated parameter $d_{1}$ is the average delay in hours at Atlanta Airport during

Table 1

Results of Estimating the Travel Time Equation for Aircraft Arriving at Hartsfield Airport, 1986

\begin{tabular}{|c|c|c|c|}
\hline Coefficient & $\mathbf{a}$ & b & d \\
\hline $\begin{array}{l}\text { Peak-period } \\
\text { t-statistics }\end{array}$ & $\begin{array}{c}0.5403 \\
(15.20)\end{array}$ & $\begin{array}{l}0.00168 \\
(15.07)\end{array}$ & $\begin{array}{l}0.2437 \\
(4.47)\end{array}$ \\
\hline $\begin{array}{l}\text { Off-peak period } \\
\text { t-statistics }\end{array}$ & $\begin{array}{c}0.5573 \\
(17.21)\end{array}$ & $\begin{array}{l}0.00156 \\
(18.87)\end{array}$ & $\begin{array}{l}0.2393 \\
(5.71)\end{array}$ \\
\hline
\end{tabular}

period i. Table 1 depicts the results of estimating Equation 2 for aircraft arriving at Atlanta Hartsfield Airport during peak and off-peak periods.

Table 1 shows an interesting result: congestion delays are almost equal during peak and off-peak periods. This finding demonstrates that traffic distribution at major hubs is almost uniform throughout the day; the morning and evening peaks are not particularly pronounced. This phenomenon can be interpreted in two ways. First, because of scarcity of resources (i.e., runway capacity, terminal facilities, etc.), airlines shift some of their operations away from the peak periods given that congestion costs during these periods would outweigh some of the economic benefits of increased passenger demand. Second, most airlines adopt a "banking" scheduling scheme for their aircraft operations at connecting hubs; aircraft arrive at a certain period followed by a bank of departures. The repetitions of this scheduling pattern during the day will likely result in a relatively uniform distribution of aircraft operations at the hub. Later in this paper (Table 2) we will see that airlines tend to fly larger aircraft during peak periods to meet the relatively high demand for air travel during these periods.

To estimate Equation 1, a profile is needed of arriving aircraft by type and the corresponding crew, fuel and main- 
tenance cost per block hour. This step also requires obtaining a large and expensive data set on flights arriving at Atlanta Airport in 1986. To reduce the cost of data acquisition, the analysis is performed in two steps. First, a profile of the annual number of aircraft arriving at Hartsfield Airport in 1986 along with the corresponding total seats was obtained. The data were retrieved from the Official Airline Guide (OAG) database as stored on the computerized tapes of Reuters Information Inc. The data profile is shown in Table 2. Second, data on crew, fuel, and maintenance costs per block hour were obtained for a number of aircraft types ranging from 100 seats
(B737) to 420 seats (B747). These data were obtained from FORM 41, Reuters Information, Inc. These cost components (in dollars per block hour) are regressed linearly against the number of aircraft seats. The slopes of the resulting regression lines are interpreted as the average cost per block hour per seat. The unit costs for crew $\left(m_{c}\right)$, fuel $\left(m_{\mathrm{f}}\right)$, and maintenance $\left(m_{m}\right)$ are estimated as $\$ 1.018$, $\$ 4.807$ and $\$ 1.507$ per block hour per seat; respectively. Equation 1 can now be reformulated as:

Equation 3

$$
A C=\sum_{1} 8 R Q S\left(\mu_{c}+\mu_{r}+\mu_{\mu}\right)
$$

Where $S_{1}$ is the average seating capacity of all aircraft arriving at period $i$; and $m_{c}, m_{r}$ and $m_{m}$ are defined above.

Table 3 depicts the calculation of airline congestion costs following Equation 3. It appears that in 1986 airlines incurred $\$ 78.42$ million in additional operating costs due to congestion delay at Atlanta Hartsfield Airport. As previously mentioned, this is a relatively conservative figure since delay costs for departing aircraft are not included in the analysis.

While one can conclude from Table 1 that aircraft operations are to some extent evenly distributed throughout the day, Table 2 shows that airlines tend to fly relatively larger aircraft during peak periods.

Table 2

A Profile of Aircraft Arriving at Atlanta Hartsfield Airport in 1986

\begin{tabular}{|l|r|r|c|}
\hline \multicolumn{1}{|c|}{ Time Period } & $\begin{array}{c}\text { Annual Flight } \\
\text { Departures }\end{array}$ & Total Number of Seats & $\begin{array}{c}\text { Average Seating } \\
\text { Capacity }\end{array}$ \\
\hline Before 6:01 AM & 935 & 117,114 & 125 \\
From 6:01 to 9:00 AM & 37,523 & $4,659,849$ & 124 \\
From 9:01 to 4:00 PM & 167,503 & $18,799,280$ & 112 \\
From 4:01 to 7:00 PM & 76,949 & $9,937,211$ & 129 \\
After 7:00 PM & 92,745 & $10,738,028$ & 116 \\
\hline Peak Period & 114,472 & $14,597,060$ & 128 \\
Off-peak period & 261.183 & $29,654,422$ & 114 \\
\hline
\end{tabular}

Source: Official Airline Guide Database, Reuters Information Inc.

\section{CONGESTION COSTS TO} PASSENGERS

Information needed to assess congestion costs to passengers includes estimates of delay for originating, terminating and connecting passengers at the hub along with a monetary valuation of passengers' travel time. As before, some assumptions should be made to simplify the analysis. For instance, passengers originating from a hub airport encounter ground delay equal to the time aircraft are held at the gate following the scheduled departure time. Likewise, passengers terminating at the hub airport encounter airside delay equal to the time aircraft circulate around the airport in holding patterns. It is, however, hard to postulate on the delay pattern for connecting traffic. A passenger arriving on a delayed flight to the hub may still be able 
Table 3

Results of Estimating Congestion Costs to Airlines

\begin{tabular}{||l|c|c|c|c|c||}
\hline \hline Time Period & $\begin{array}{c}\text { Annual Flight } \\
\text { Arrivals }\end{array}$ & $\begin{array}{c}\text { Average } \\
\text { Seating } \\
\text { Capacity }\end{array}$ & $\begin{array}{c}\text { Sum of unit } \\
\text { costs }\end{array}$ & $\begin{array}{c}\text { Average } \\
\text { Delay (hours) }\end{array}$ & $\begin{array}{c}\text { Airline Cost } \\
\text { (\$ millions) }\end{array}$ \\
\hline $\begin{array}{l}\text { Peak period } \\
\text { Off-peak } \\
\text { period }\end{array}$ & 114,472 & 128 & 7.332 & 0.2437 & 26.18 \\
\hline $\begin{array}{l}\text { Total Alrline } \\
\text { Cost }\end{array}$ & 261,183 & 114 & 7.332 & 0.2393 & 52.24 \\
\hline
\end{tabular}

to board a connecting flight and depart on time; the arrival delay at the hub is thus compensated for by less transfer time at the terminal. Because of the difficulties of assessing the exact delay pattern for connecting passengers we ignore the effects of delay on those passengers. Again, this is a more conservative approach and the estimated delay cost in this study is merely a demonstration of the minimum impact of delay on passengers. The delay cost to passengers is given as:
Equation No. 4

$$
P C=V \sum_{1}\left(D P P_{d}+A P P_{d}\right)
$$

Where $D P_{1}$ is the number of passengers originating from the hub region and departing during period $i ; d_{d l}$ is the average ground delay during time $i ; A P_{i}$ is the number of passengers terminating at the hub and arriving during period $i$; and $d_{a l}$ is the average airside delay during period $i$. $V$ is a monetary valuation of passenger time in terms of dollars per hour.
Equation 4 is again estimated for the peak and off-peak periods. Note that the values of delays for arriving aircraft during these periods were already estimated as shown in Table 1. Using data for 308 non-stop flights (of which 181 were during peak periods) operated by Delta Airlines in 1986, Equation 2 is estimated for departing flights. The results of this estimation are shown in Table 4. To estimate Equation 4, one should have a Time-of-Day profile of passengers originating from and termi-

\section{Table 4}

Results of Estimating the Travel Time Equation for Alrcraft Departing from Hartsfield Airport, 1986

\begin{tabular}{||l|c|c|c|}
\hline Coefficient & $a$ & $b$ & $d$ \\
\hline Peak-period & $\begin{array}{c}0.5473 \\
(17.69)\end{array}$ & $\begin{array}{c}0.00158 \\
(17.71)\end{array}$ & $\begin{array}{c}0.2231 \\
(5.35)\end{array}$ \\
t-statistics & $\begin{array}{c}0.5814 \\
(18.47)\end{array}$ & $\begin{array}{c}0.00145 \\
(16.84)\end{array}$ & $\begin{array}{c}0.1962 \\
(4.17)\end{array}$ \\
\hline $\begin{array}{l}\text { Off-peak period } \\
\text { t-statistics }\end{array}$ & & & \\
\hline
\end{tabular}

nating at Hartsfield Airport. Since these data are unavailable in any form, we need to assume: (a) originating and terminating passengers constituted about $65 \%$ of the $21,824,125$ enplanments at Hartsfield in 1986; and (b) passenger demand for travel during peak and off-peak periods is proportional to the number of aircraft seats during these periods. Table 6 shows the distribution of passengers during these time periods based upon the above assumptions.

To estimate a valuation of passenger time, we develop a 
passenger's utility function in which price (airfare) and travel time are included as explanatory variables. The marginal rate of substitution between these two variables is a monetary valuation of a passenger's travel time. This approach has been used in several transportation studies (Kanafani, 1985). A passenger's utility function of traveling a particular route which joins the origin and destination cities can consist of frequency of service, travel time, airfare, and the average seating capacity of the aircraft. In this case, the passenger utility function is given as:

\section{Equation No. 5}

$U_{r}=a F Q_{r}+b T_{r}+g F R_{r}+f S_{r}+\theta$
Where $U_{r}$ is the passenger's utility function of traveling route $r$, $F Q$, is flight frequency on route $r, T$, is the travel time in hours on route $r, F_{r}$ is the "weighted" average airfare on route $r$, and $S$, is the average aircraft size (number of seats) on route $r . a, b, g$, $f$ are the parameters of the utility function and $e$ is the error term.

From Equation 5, one can

Table 5

Results of Estimating the Utillity Function in Equation 5

\begin{tabular}{||l|c|c|c|c|}
\hline \multicolumn{1}{|c|}{ VARIABLE } & Frequency & $\begin{array}{c}\text { Time } \\
\text { (HOURS) }\end{array}$ & $\begin{array}{c}\text { AMRFARE } \\
\text { (DOLLARS) }\end{array}$ & $\begin{array}{c}\text { SEATNa } \\
\text { CAPACITY }\end{array}$ \\
\hline $\begin{array}{l}\text { Estimated coefficiency } \\
\text { t-statistics }\end{array}$ & $\begin{array}{c}0.3051 \\
(3.73)\end{array}$ & $\begin{array}{c}-0.5682 \\
(-2.04)\end{array}$ & $\begin{array}{c}-0.01035 \\
(-2.93)\end{array}$ & $\begin{array}{c}0.00606 \\
(2.02)\end{array}$ \\
\hline $\begin{array}{l}\text { R-Squared } \\
\begin{array}{l}\text { Log-Likelihood at: } \\
\text { zero slope } \\
\text { convergence }\end{array}\end{array}$ & 0.49 & & & \\
\hline
\end{tabular}

Table 6

Results of Estimating Congestion Costs to Passengers

\begin{tabular}{|c|c|c|c|c|c|}
\hline & & $\begin{array}{l}\text { Delay } \\
\text { (Houns) }\end{array}$ & $\begin{array}{c}\text { TIME VALUE } \\
\text { (\$/Houp) }\end{array}$ & $\begin{array}{l}\text { Number of } \\
\text { Passenceas }\end{array}$ & $\begin{array}{c}\text { Delay Costs } \\
\text { (\$ Millions) }\end{array}$ \\
\hline \multirow[t]{2}{*}{ Peak Periods } & Arriving & 0.2437 & 55 & $2,519,663$ & 33.78 \\
\hline & Departing & 0.2231 & 55 & $2,394,233$ & 29.38 \\
\hline \multirow[t]{2}{*}{ Off-peak Periods } & Arriving & 0.2393 & 55 & $5,244,211$ & 56.59 \\
\hline & Departing & 0.1962 & 55 & $5,118,781$ & 63.37 \\
\hline \multicolumn{4}{|c|}{ Total Conoestion Costs to Passencears } & \multicolumn{2}{|c|}{183.12} \\
\hline
\end{tabular}

derive the rate of substitution between airfare and time to be $(\mathrm{b} / \mathrm{g})$ which is a valuation of passenger time in dollars per hour. Assuming passengers exhibit utility maximization behavior in route selection, the standard multinomial logit probabilistic choice model can be obtained such that:

Equation No. 6

$$
P_{r}=\frac{\theta U_{T}}{\sum \cdot 4}
$$

Where $P_{r}$ is the probability that passengers chose route $r$ among the different routes joining the origin and destination cities, and $U_{r}$ is the passenger's utility function in terms of the service attributes of route r. For a thorough discussion and 
derivation of the logit model, see Kanafani (1985). To estimate the parameters of the utility function in Equation 5, we use travel data for 62 markets flown by Delta Airlines in 1986 in the Southeastern region of the U.S. The data were obtained from both DATABANK $1 A$ and the OAG databases as stored on the computerized tapes of Reuters Information Inc. Table 5 shows the results of estimating Equation 5. All estimated the parameters are statistically significant at 0.05 level and their signs are meaningful (i.e., frequency has a positive coefficient and airfare has a negative one). Using the parameters in Table 5, one can estimate a valuation of passen- ger time to be about $\$ 55$ per hour. This figure seems reasonable. Following the same approach presented here, (Kanafani \& Ghobrial, 1985) used data on economy class airfare to calibrate a route choice model similar to that in Equation 5. They estimated a valuation of passenger time to be about $\$ 32$ per hour in 1979. Here we use the weighted average airfare of all classes of service in 1986.

From Table 6, it seems that congestion cost is about $\$ 183$ million for both originating and connecting passengers. This is, again, a more conservative figure as it excludes the time cost for connecting passengers. CONCLUSIONS

This study attempts to quantify the congestion costs to both airlines and passengers at Atlanta Hartsfield Airport in 1986. Using simple techniques, we estimate the combined cost to be about $\$ 260$ million. This figure excludes the impact of congestion on ATC facilities, airport, and environment. The negative economic impacts of congestion at Atlanta Hartsfield Airport ought to be considered when conducting benefit-cost analyses of upgrading airport facilities or constructing a reliever airport in the Metropolitan Atlanta area. This study can be extended further by quantifying the impact of congestion to other elements on the aviation system such as airports, ATC facilities, and the environment.

Atef Ghobrlal earned a Ph.D. in Transportation from the University of California at Berkeley, where he also earned a Master of Business Administration, and a Master of Science in Civil Engineering. An Associate Professor at Georgia State University, he directs the aviation administration program. A published author, he is also a transportation consultant in the United States and abroad.

Kenneth H. Fleming earned a Ph.D. in Economics, and M.A. in Economics, both at the University of California at San Diego, and a B.S. in the U.S. Air Force Academy. Presently, he is Chairman of the Aviation Business Administration at Embry Riddle Aeronautical University. In addition to having taught Economics and serving as a Consultant, Dr. Fleming has approximately 3,000 hours flying experience.

\section{REFERENCES}

Douglas, G., Miller, J. III (1974). "Economic Regulation of Domestic Air Transport: Theory and Practice", Washington, DC: Brookings Institution.

Ghobrial, A. (1991). Competition for Hub Dominance: Some Implications to Airline Profitability and

Enplanement Share, The Journal of Aviation/Aerospace Education and Research. 2(1), 20-29.

Horonjeff, R., McKelvey, F. (1983). Planning and Design of Airports, 3rd edition. New York: McGraw Hill. Kanafani, A. (1985). Transportation Demand Analysis, New York: McGraw Hill.

Kanafani, A., Ghobrial, A. (1982). 'Aircraft Evaluation in Air Network Planning.' Transportation

Engineering Journal of the American Society of Civil Engineering, 108(TE3), pp. 282-300.

Kanafani, A., Ghobrial, A. (1985). "Airline Hubbing-Some Implications for Airport Economics"

Transportation Research, 19A(1) pp. 15-27.

Miller, James (1979). 'Airline Market Shares Versus Capacity Shares and The Possibility of Short-Run

Loss Equilibria', Research in Law and Economics, 1, pp. 81-96.

Transportation Research Board (1988). The Future Development of the U.S. Airport Network:

Preliminary Report and Recommended Study Plan", Washington, DC: Authorn 